\title{
Cervical nodal metastasis in head and neck cancer: a clinical conundrum
}

\author{
Swaroop Revannasiddaiah, ${ }^{1}$ Ashwani Sood, ${ }^{2}$ Sudesh Kumar, ${ }^{3}$ Priyanka Thakur ${ }^{4}$
}

${ }^{1}$ Department of Radiation Oncology, Swami Rama Cancer Hospital and Research Institute, Haldwani, Uttarakhand, India ${ }^{2}$ Department of Nuclear Medicine, Postgraduate Institute of Medical Education and Research, Chandigarh, India

${ }^{3}$ Department of Otolaryngology and Head Neck Surgery, Sultan Qaboos University Hospitals, Muscat, Oman ${ }^{4}$ Regional Cancer Centre, Shimla, Himachal Pradesh, India

\section{Correspondence to}

Dr Swaroop Revannasiddaiah; swarooptheone@gmail.com

\section{CrossMark}

To cite: Revannasiddaiah $S$, Sood A, Kumar S, et al. BMJ Case Rep Published online: [please include Day Month Year] doi:10.1136/bcr-2013010364

\section{DESCRIPTION}

Within a month of being treated with a partial maxillectomy for a stage $T_{2} \mathrm{~N}_{0} \mathrm{M}_{0}$ (staged as per preoperative MRI and CT) left maxillary antral carcinoma, a patient suffered symptoms of 'sore throat' and also tested positive for a streptococcal infection on a swab test. Though appropriate antibiotics relieved symptoms, a minimal dysphagia persisted which was conveniently attributed by the patient as 'being related to the streptococcal infection'.

However, after two months, the ${ }^{18} \mathrm{~F}$-fluorodeoxyglucose positron emission tomography/CT $\left({ }^{18} \mathrm{~F}-\mathrm{FDG}-\mathrm{PET} / \mathrm{CT}\right)$ which was performed as part of a post-treatment follow-up, demonstrated multiple contralateral avid necknodes (levels II-IV). This was histopathologically confirmed to be harbouring metastatic deposits of squamous cell carcinoma (figure 1).

Given the sparsity of lymphatics to the maxillary antrum, the possibility that lymph nodal spread from a $T_{2}$-staged maxillary antral carcinomas is very unlikely. ${ }^{1}$ In this described case, the postoperative histopathology demonstrated negativemargins also the FDG-PET scans ruled out recurrence at the primary site.

The use of FDG-PET for the assessment of the $\mathrm{N}_{0}$ neck may be constrained by the combination of limited sensitivity for small metastatic deposits and a relatively high number of false-positive findings in PET/CT, thus highlighting the point that the surgical management of the clinically $\mathrm{N}_{0}$ neck should not be
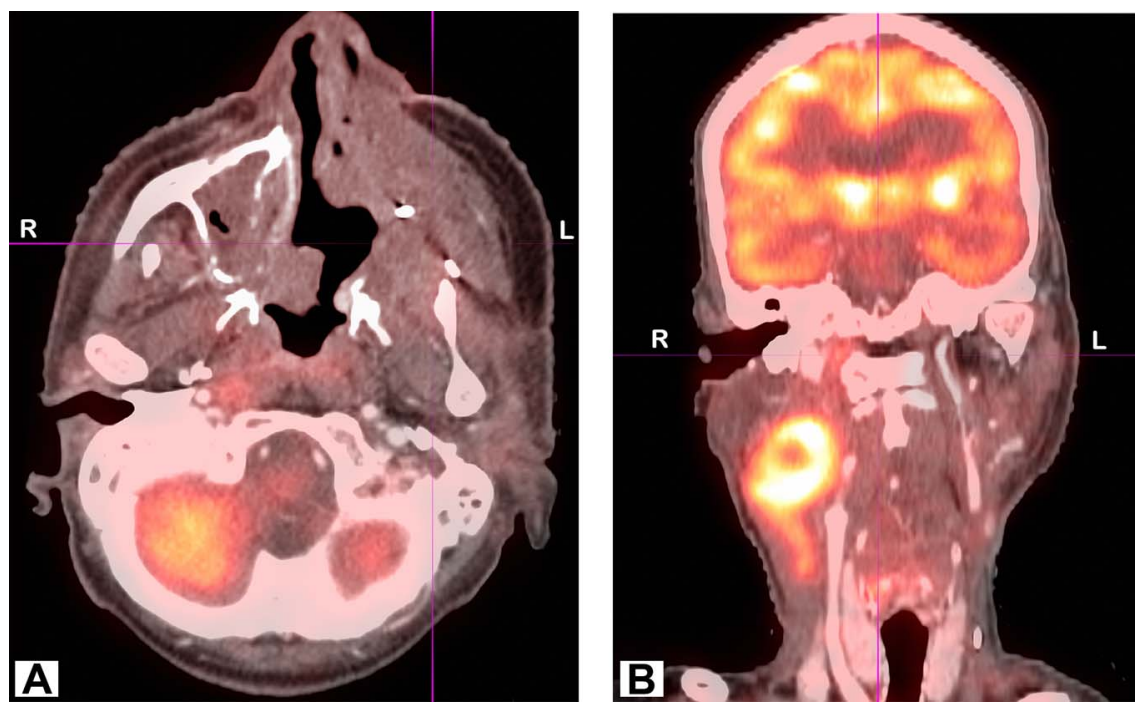

Figure $1{ }^{18} \mathrm{~F}$-fluorodeoxyglucose positron emission tomography/CT obtained 3 months postoperatively demonstrating no metabolic activity in the tumour bed (A), whereas a highly avid (maximum standardised uptake value 16.4) mass is found in the contralateral aspect of the neck (B). solely based on the findings on a standard CT or a FDG-PET/CT scan. ${ }^{2}$

Owing to the low likelihood of the metastatic neck nodes having originated from the maxillary antral cancer, that too to the contralateral side, a search for another site of head and neck mucosal malignancy was performed. However, as no other aerodigestive mucosal malignancy was found, he has since been initiated on chemoradiotherapy on the lines of a 'metastatic-neck-node from unknown-primary'.

\section{Learning points}

- Malignancy of the head and neck can often hide under the symptomatology of common diseases.

- The assessment of the $\mathrm{N}_{0}$ neck by imaging techniques such as CT and

${ }^{18} \mathrm{~F}$-fluorodeoxyglucose positron emission tomography (FDG-PET) may be constrained by the combination of limited sensitivity and poor positive predictive value for small metastatic deposits.

- The use of FDG-PET scan in the follow-up of patients treated for cancer is likely to provide higher sensitivity and higher negative predictive value in the detection of disease recurrence in comparison to the use of standard CT alone (figure 2). ${ }^{3}$ 


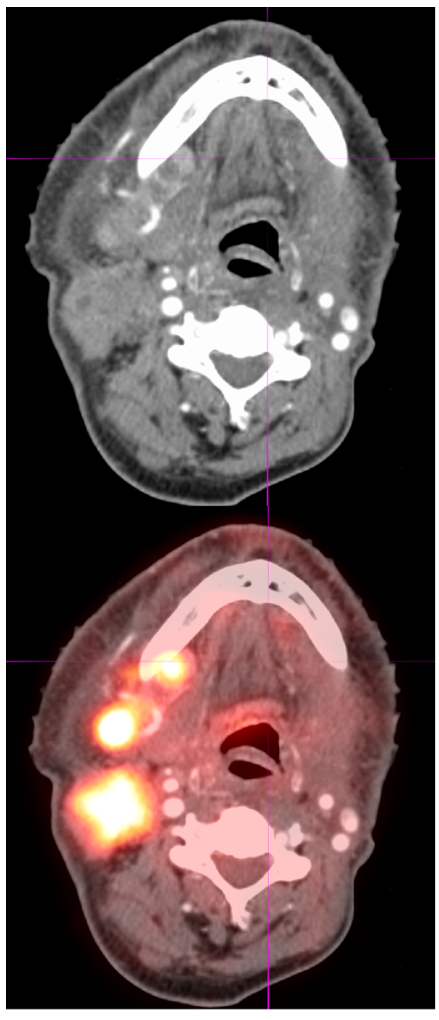

A



B

Figure 2 Comparison of CT alone and positron emission tomography/CT (PET/CT) slices at two different levels. While the enlarged lymph nodes in the right level II area can easily be visualised on a simple CT scan (A), it must be noted that at a lower level in the neck, though the transverse CT section appears normal with no abnormal mass, the complementary PET/CT section has registered a highly avid (maximum standardised uptake value $11 ; B$ ). This depiction by PET of metabolically active disease at locations appearing normal on CT emphasises the importance of integrating $\mathrm{PET} / \mathrm{CT}$ in the routine follow-up of patients with head and neck cancers.

Contributors AS provided the images. SR identified the case for publication. SK wrote the initial manuscript and PT performed a literature review and prepared the final version of the manuscript.

\section{Competing interests None.}

Patient consent Obtained.

Provenance and peer review Not commissioned externally peer reviewed.

\section{REFERENCES}

1 Le QT, Fu KK, Kaplan MJ, et al. Lymph node metastasis in maxillary sinus carcinoma. Int J Radiat Oncol Biol Phys 2000;46:541-9.

2 Schoder H, Carlson DL, Kraus DH, et al. 18F-FDG PET/CT for detecting nodal metastases in patients with oral cancer staged NO by clinical examination and CT/ MRI. J Nucl Med 2006;47:755-62.

3 Andrade RS, Heron DE, Degirmenci $B$, et al. Posttreatment assessment of response using FDG-PET/CT for patients treated with definitive radiation therapy for head and neck cancers. Int J Radiat Oncol Biol Phys 2006;65:1315-22.

Copyright 2013 BMJ Publishing Group. All rights reserved. For permission to reuse any of this content visit http://group.bmj.com/group/rights-licensing/permissions.

BMJ Case Report Fellows may re-use this article for personal use and teaching without any further permission.

Become a Fellow of BMJ Case Reports today and you can:

- Submit as many cases as you like

- Enjoy fast sympathetic peer review and rapid publication of accepted articles

- Access all the published articles

- Re-use any of the published material for personal use and teaching without further permission

For information on Institutional Fellowships contact consortiasales@bmjgroup.com

Visit casereports.bmj.com for more articles like this and to become a Fellow 